\title{
Russianness in the Works of European Composers
}

\author{
Liudmila Kazantseva \\ Department of Theory and History of Music \\ Astrakhan State Concervatoire \\ Astrakhan, Russia \\ E-mail: kazantseva-lp@yandex.ru
}

\begin{abstract}
For the practice of composing a conscious reproduction of native or non-native national style is traditional. As the object of attention of European composers are constantly featured national specificity of Russian culture. At the same time the "hit accuracy" ranges here from a maximum of accuracy (as a rule, when finding a composer in his native national culture) to a very distant resemblance. The out musical and musical reasons for reference to the Russian culture they are considered in the article. Analysis shows that Russiannes is quite attractive for a foreign musicians. However the European masters are rather motivated by a desire to show, to indicate, to declare the Russianness than to comprehend, to go deep and to get used to it.
\end{abstract}

Keywords-Russian music; Russianness; Western European composers; style; polystyle; stylization; citation

\section{INTRODUCTION}

Conscious reproduction of national or other-national features of musical style for compositional practices is traditional. "National / foreign" is often treated by the European at the continental style level (term of Catherine Ruch'evskaya), when other-national is seen as eastern (Japanese, Chinese, Indian) or as western - American (personalized by jazz, as we can say, Ravel, Debussy, late Rachmaninoff).

At the level of the style of the national culture there are also intensive interactions. Russian musicology is actively investigating penetration of the "alien" in the "native" culture, say, Western, and in recent times - and oriental influence on Russian music (on Alexander Alyabjev, Mikhail Glinka, Mikhail Ippolitov-Ivanov, Sergey Rachmaninoff, Alexander Scriabin) $[1 ; 3 ; 4 ; 6 ; 10]$. However, formulation of the other problem is no less informative and productive for the study: how some - in this case Russian rooted national characteristics are displayed by representatives of other cultures.

As other-national origin in European music Russian music often appears. This phenomenon gives rise to many questions. One of them is the historical evolution of interest in the specifics of Russian music, with its "flows" as it is evident in the XVIII - early XIX centuries, and with fades. The other is the degree of adequacy, that is, variations under the "hit exactness" from the maximum accuracy (usually with organic joining of West European composer to the Russian national culture) to very distant similarity (when the
Russianness is seen more as an exotic). As one more question I'll name the ways and means of capturing Russian origin.

Not turning further on the fan of questions that determine the development of the problems of Russian as othernational, let's focus on only one of them: the reasons which encourage European composers in one form or another to turn to Russian culture and to make it the subject of a creative image.

\section{THE OUt MusicAl REASONS FOR REFERENCE TO THE RUSSIAN CULTURE}

In general, the reasons can be grouped as follows: out musical and musical. I refer to out musical primarily major historical and cultural processes in Europe, due to which there was the migration of musicians and exchange of cultural achievements. These processes were mutual, but uneven. Thus, in the XVIII century there was truly a grand inflow of foreigners to Russia. Following the Italian opera groups composers appeared, many of whom came into contact with Russian music. For the entertainment of the imperial court and the aristocracy, and for teaching music Francesco Domenico Araja, Baldassarre Galuppi, Catarino Camillo Cavos, Giovanni Paisiello, Domenico Cimarosa came here from Italy; Johann Leopold Fuchs - from Germany; Irish composer John Field, French opera composer François Adrien Boieldieu, Spanish Vicente Martín y Soler, and many others - from other countries ${ }^{1}$. This inflow weakens later in XIX century, when Russian music generates own specialists, but does not run at all.

Serious motivations of careful attention to the life of the Russian man and his culture were great historical events of public interest, which were reacted by musicians. At the beginning of XIX century that was undoubtedly the war of 1812 between Russia and Napoleon's troops. In program instrumental rhapsody compositions of that time alternating episodes of warfare developed. Events are accompanied by feelings of grief from the loss or the joy of victory, distinct in piano fantasies of German pianist, conductor and composer Daniel Steibelt "Image of Moscow in flames" and "The Return of the Russian cavalry to St. Petersburg on October

\footnotetext{
${ }^{1}$ The vast number of musicians, who worked in Russia for a long time and even moved there, are called fine art expert, who for half of XVIII century has seen life at the courts of the Russian emperors, Jakob von Staehelin [13] and leading expert on Russian music Nicholas Findeyzen [12].
} 
18,1814 ", in the musical picture of Italian conductor and violinist Giuseppe Truffo "On the war stogneys (August, 5, 1812)" in words of M. Lentovsky (published in 1903). This is what the program of one more "musical picture" - "Epic of 1812" for piano Composition 164 by actual member of the Society of European composers Vladimir Christian Davinhoff, which has consistently been discharged in the note text:

“The French army is close to Moscow. Napoleon's entry into Moscow. Disturbing bells of Ivan the Great [campanile]. Napoleon rode joyfully to the Kremlin. Muscovites, weeping and wailing, set fire to the whole capital. Napoleon is despairingly retreating. Ringing of Kremlin bells informs people about the beginning of a thanksgiving prayer. Alleluia, Alleluia, Glory to Thee, O God, Alleluia, Alleluia, thank you, God. Alleluia, Alleluia, Glory to Thee, O Lord. Amen, Amen. Hurrah! Hurrah!".

In such "musical pictures" or "historical plays", "war plays", which continue the tradition of "Wellington's Victory, or the Battle of Vittoria" by Ludwig van Beethoven, and going back to "musical battles" of Sweelinck, Frescobaldi, Froberger, Janequin and English virginalists, simple plot quite schematically unfolds, receiving exemplary music solution that strengthens theatrical element in them.

Other military triumphs of Russia are marked by music premieres. Giuseppe Sarti willingly wrote such works, who coincided to the capture Ochakov of the Russian army the oratorio "You, God, praise" (Te Deum) (1789) for three hundred singers and instrumentalists, church bells and cannons ${ }^{2}$. Russian life enters to these and similar plays by program titles, as well as many onomatopoeic-illustrative details.

Such outstanding political actions were historically significant, as the coronations, state or private visits of the regnant persons to European countries. They have also become the reason for the emergence of musical compositions. A number of "Russian" opuses caused by socially important event belongs to Johann Strauß, whose relationships with Russia could be the subject of a separate study. Cantata "The genius of Russia" (1797) by Giuseppe Sarti for the coronation of Paul I, the play "The Joy of Moscow: the solemn march on the occasion of the entry of Their Imperial Highness sire cesarevitch Alexander Alexandrovich and monarchess Maria Feodorovna" by the German composer and pianist Ferdinand Beyer, Marsh on the coronation of Alexander II for Piano, Op. 35 (1856) by Adolph von Henselt and other works "on occasion", that are confined to any event of national importance, are usually pragmatic, "etiquette" in nature. They solemnly declaratively celebrate major public figure or the Russian people and usually don't present the special artistic value.

\footnotetext{
${ }^{2}$ To have more information about the music associated with the events of World War II in 1812, see the publications N.A. Ryzhkova [7; 8; 9], as well as the article "The National War of 1812 in the Russian music (search for primary sources)" N.E. Tropina, which contains a directory of music dedicated to the War of 1812 [11].
}

In subject, connected with Russia, the figure of Tsar Peter I has acquired a prominent place which his oratorio "Peter the Great" (1831) by music theorist, teacher and composer Johann Leopold Fuchs was dedicated. European composers clearly came to the liking of the episode (probably fictional) from the Russian past, described by Voltaire in his "History of Peter I": during the Great Embassy to the Netherlands in 1697, the young tsar studied shipbuilding in Saardame under the name of Ivan Mikhailov and worked as a carpenter. Under this plot there was written comic operas "Peter the Great" (1790) by André-ErnestModeste Grétry, "Youth of Peter the Great" (1794) by Joseph Weigl, "The Burgomaster of Sardam" (1818) by Henry Rowley Bishop, "Peter the Great, the tsar of Russia or Livonian carpenter" (1819) and "The Burgomaster of Sardam" (1827) by Gaetano Donizetti, "The North Star" (1854) by Giacomo Meyerbeer, drama-buffoon "Peter the Great, or torments of jealousy" (1824) by Nicola Vaccai, operetta "The Tsar and the carpenter" (1837) by Albert Lortzing, and other works.

No less important ones were the biographical reasons of interest of European composers to Russian musical culture those occasions, dictated by their life, biographical circumstances. Czech musician Štěpán Rak was born in 1945 in the Ukrainian village, was abandoned by parents, chosen by the Soviet troops and was brought to Prague by tank, where he was grown by a family of local residents. Becoming a world-renowned guitarist and composer, he devoted several plays to Russia for his instrument ("Russian Waltzes", "Russian Caravan", "Russian Thought", "Balalaika").

Foreign musicians, who lived for a long time in Russia, naturally turned to the Russian topic. Having been invited to Russia on tour or court service, they were here to stay for a long time, or even forever. They wrote for the opera stage, church, cabin pastime and teaching music. Growing into the culture of their adopted country, and making a significant contribution to the transformation of musical life in Russia, such composers and performers sometimes rightly positioned of researchers as essentially Russian.

The life circumstances of Johann Strauß were noteworthy in this regard. Composer came to Pavlovsk from 1856 for 10 years and arranged the musical seasons, which attracted all the Petersburg nobility and members of the royal family. Creative response to the impressions of Russia and known vicissitudes of his personal life became dedicated to Princess Olga "Olga"-Polka, Op. 196, polka-quasi-gallop "Pavlovskaya" Op. 184b, polka-mazurka "Minx" Op. 226, dedicated to Olga Smirnitskaya in which Strauss was in love with, polka-mazurka "On the Volga" Op. 245, fantasy "In Russian village" op. 355, "Russian march-fantasy" Op. 353, the waltz "Farewell to St. Petersburg" op. 210, "Violet mazurka" Op. 256 on Russian themes, quodlibet "An offering to the Russian public", and other works.

Not only long stay in Russia, but even short visits to the country stimulated interest in its culture. This pattern is quite evident in the biography of Ferenc Liszt. He traveled to Russia with performances on three occasions (1842, 1843 
and 1847), which was contributed by a lot of deep personal attachment to the Princess Caroline Wittgenstein (Ivanovskaya). In 1842, as a young but well-known musician in Europe, he saw a production of "Ruslan and Lyudmila" by Michael Glinka, praised the opera, and wrote a piano transcription of the "Chernomor's March", which was included in his repertoire. He met with the "brilliant dilettantes" (Robert Schumann) Knyaz Vladimir Odoyevskiy and Count Michael Wielhorsky, made the friendships with members of the "Mighty Handful" ("The Five"). Creative continuing of these contacts was in transcriptions [5], publications, and concert performances of works of Russian musicians and even joint creative projects ${ }^{3}$.

An eminent English composer Benjamin Britten, a friend of Dmitry Shostakovich, Mstislav Rostropovich and Galina Vishnevskaya, repeatedly visited the USSR (1963, 1964, 1971). The result of one of these trips was a song cycle "The Poet's Echo" on words of Alexander Pushkin, Op. 76 (1965), written for Galina Vishnevskaya and Mstislav Rostropovich, and composed for Rostropovich Third cello Suite, Op. 87 (1971), which uses Russian folk melodies.

It is necessary, however, to say that between the duration or frequency of staying in Russia of musician and creative predisposition to its culture direct dependence is not established. Often foreigners who served in the royal court and exported its culture (Baldassarre Galuppi, Tommaso Traetta, Giovanni Paisiello, Domenico Cimarosa, Vincenzo Manfredini, François Adrien Boieldieu), were creatively indifferent to Russian music. Observations show that the biographically caused treatment to Russian culture give mixed results, and the Russianness can be quite superficial, very indirectly - through a program or a Russian verbal text - getting into music.

In most cases, the composer's intention is supported in the word - the name of the program or use the Russianspeaking literary text. Early "Russian Opera" and "Russian Romances", "Russian oratorio" of J. Sarti, ballets on the subjects of Russian fairy tales and literary works appealed to the word. . Often texts of Vasily Zhukovsky, Catherine II, later Alexis Apukhtina, Alexander Pushkin, Athanasius Fet, Yakov Polonsky and other poets actually embodied the Russian principle, not detectable in the music. The idea of dialogue with the Russian culture through word is also fruitful for the later generations of musicians: in the opera "Katya Kabanova" (after the play "Storm" Ostrovsky, 1921) and "House of the Dead" (according Dostoevsky, 1928), Rhapsody for orchestra "Taras Bulba" (by N. Gogol, 1915 1918), Leos Janacek, in ""Requiem" by Anna Akhmatova" (1980) and the play "The Death of Ivan Ilyich" (after L. Tolstoy, 2012) for soloists and orchestra Englishman John Tavener; in the ballet "Goldfish" (after the tale by Pushkin, 1866) of Ludwig Minkus. Russian literature was and remains up to now inexhaustible extra musical source of inspiration of the European composers. Many composers paid tribute to

\footnotetext{
${ }^{3}$ After reading "Paraphrase on the continuing theme" - variations of A.P. Borodin, Ts.A. Cui, A.K. Liadov and N.A. Rimsky-Korsakov, on the Borodin's polka theme called by V. Stasov "Tachi-tachi” (1878-1879), and went to the delight - Liszt himself wrote several variations. Supplemented "Paraphrases" were published by M.P. Belyaev in Leipzig in 1893.
}

the works of Alexander Pushkin, Anton Chekhov, Fyodor Dostoyevsky, Nikolay Gogol and other authors in their operas. A lot of vocal miniatures have known which are based on the works of Russian poets.

\section{THE MUSICAL REASONS FOR REFERENCE TO THE RUSSIAN CULTURE}

Properly musical reasons for reference to the Russian culture are numerous and varied. Among them is the reproduction of a musical-"language" signs of Russian music. A convincing indication of the national origin for many European authors is an imitation of the respective musical instruments. The personification of Russian in the play «Balalaika» for guitar by the Czech composer and guitarist Štěpán Rak (b. 1945) - author masterfully imitates the Russian musical instrument. Indispensable attribute of Russians living - chimes - ends Fantasia "in Russian village", Op. 355 by Johann Strauss. The bravura finale of the Sonata N 1 fis-moll for piano (1921) by Englishman Arnold Bax (1883 - 1953) is heard ringing of the Easter bells. In the finale of the Sinfonia in C Major by German composer August Ferdinand (Antonio Ferdinand) Tietz (Titz, Dietz, Dietzsch, 1742 - 1810/1811) the topic of dance in the Russian style appears in the whole "folk orchestra": the melody join echoers oboes and a droning "bagpipe" bass.

Composer can be moved by the wish to catch and pass the specific features of different national styles of music, including Russian. Polystyle creative landmarks are typical for Dutch composer and pianist Joseph Ascher, of whom among "Danse espagnole", "La plainte indienne", "Danse nègre", opus "Muscovite. National Dance" for piano naturally looks. The French composer Édouard-VictoireAntoine Lalo next to "Spanish Symphony", "Norwegian Rhapsody" and "Norwegian fantasy" has "Russian Concert" for violin and orchestra, Op. 29 (1879).

It is particularly natural that interest in different cultures presses to polystyle concept of a work, kaleidoscopic multistyle coverage of sources, among which Russian is also listed. In that case, a special creative task becomes musical "map of the world". In Ludwig van Beethoven's "10 varied subjects for Piano with accompaniment of flute or violin", op 107 along with Tyrolean, two Russian melodies sound. In opus 158 "Songs of Various Nationalities" more multielement, multinational whole was composed by him from the Danish, German, Tyrolean, Polish, Portuguese and other songs, including four Russian there.

There is truly grandiose idea of Johann Strauß, composed for the festival "Musical evening entertainment for the Slavs", "Slavic quodlibet" Op. 39 (1847): he joined in the play more than twenty Moravian, Bohemian, Czech, Serbian, Polish and other melodies, among which tune of romance by Alexander Varlamov "Red Sarafan" is signified under No. 6. The evening was attended by over a thousand guests, representatives of the Slavic peoples. Under the comment of "Vienna universal theatrical newspaper" from March 31, 1847 , - quote - "it was very interesting; when against the general applause increase was arising from a single house, then another, when each group of Slavic people heard the 
melody of their homeland". The idea of an infinitely variegated suite-kaleidoscopic set of song and dance musical themes was very close to Strauss.

There is a series of polkas "Northern Belle", made in the tradition of concise instrumental female portrait, common in French music, for example, Francois Couperin (Four trio "Nation", "The French", "Spanish Flu", "Empress", "Pemontka") in the heritage of French pianist and Austrianborn composer Henri Herz (1803 - 1888), in 1859 on tour in Russia. This series included "Polka", "Gypsy", "Hungary's", "Germany's", "Muscovite", "Swede".

Russianness can act both as a special creative activity in stylization. In such cases, the same is usually not only manifested in the title of the program, which includes the word "Russian", but also involves reproduction music and language appropriate signs. Examples of this kind - play No. 7 of the third cycle of "Three Miniatures for Piano Trio" (1908), "Russian Waltz" by English composer, violinist and conductor of the theater "Covent Garden" Frank Bridge, "In the Russian style" of twenty-four frequency cycle of plays "Variegated cavalcade" op. 30 (1840?) for violin and piano by German violinist, composer, conductor, teacher, Ferdinand David, which was arranged for piano Ferenc Liszt as "Russian Song" - "Fig. 1".



Fig. 1. Ferenc Liszt. "Russian Song” for piano.

Interpretation of Russianness deserves special discussion. There are reviewed two trends. One of them is the understanding of Russianness rather as historical and geographical realities, rather than the corresponding ethnic identity. That is why, therefore, the Russian Empire in the late XVIII - XIX centuries absorbed the Ukraine and Poland, while composers might well call as the Russian, for example, the Ukrainian. So, in works of Ludwig van Beethoven, Daniel Steibelt, Johann Strauß as Russianness appears the Ukrainian melody "The Cossack went for the Danube". Based on the same considerations Arnold Bax names the second play of "Two Russian Tone-Pictures" for Piano (1912), "Gopak. National Dance", despite belonging of gopak to the Ukrainian culture. For Štěpán Rak in "Russian Thought" for guitar in the second half of the twentieth century, the Russianness came together in Ukrainian and Polish song genre of thought and occasional intonations of the Ukrainian folklore. Symptomatically full title of the Czech Arnošt Vančura: "Russian Symphony on the Ukrainian themes". As the personification of Russian and sometimes Polish culture acts: in the "Russian Dance" from "The Bat" (1874) by Johann Strauß and in piano play "Muscovite. National Dance" by Joseph Ascher Polish mazurka is easily recognizable.

Another trend is the opposite: it is the wish to capture the ethnic specificity and even detalization of Russianness, such as Cossack ("Cossack Dance", № 5 from Suite "Russian Scenes" of five pieces for small orchestra by Granville Bantock; play № 3 "In Russia: Cossack cavalry attack” from the cycle "War Pages" for piano in four hands, Op. 25 by Alfredo Casella), as Gypsy (association by Ferenc Liszt in "Two Russian melodies" for piano (1842), "Nightingale" of Alexander Alyabiev and "Gypsy Song" ("You would not believe how you're cute") by Peter Bulakhov).

Of course, the question, of how Western composer is sensitive to an alien culture, how Russianness is adequately played, is inevitable. This question requires a special study. So far, covering a large block of stylization samples, we can say that their range extends from the pseudo-Russian style to bold authorial transformation of original national style (in the play No 90 "In the Russian style" from the piano collection "Microcosmos" of the Hungarian composer Bela Bartók "Fig. 2".

The development of musical property of Russia with the citation becomes the creative task also. Among the borrowings tunes predominated, common in urban life, there are military signals (in the "Rondo alla Cosacca" by Henri Herz, battle plays on the events of 1812, numerous marches). Peasant folklore comes here from the pages of published collections, Western masters little known "authentic" sort of its. Let's pay tribute to the Czech Ivan Práč, the originator of "Assembly of Russian Folk Songs with their voices" (1790) - these folk sources fueled West European and Russian composers. The simplest way to learn Russianness (as, indeed, any other national origin), is, of course, numerous variations on folk and authorial themes for piano and other instruments.

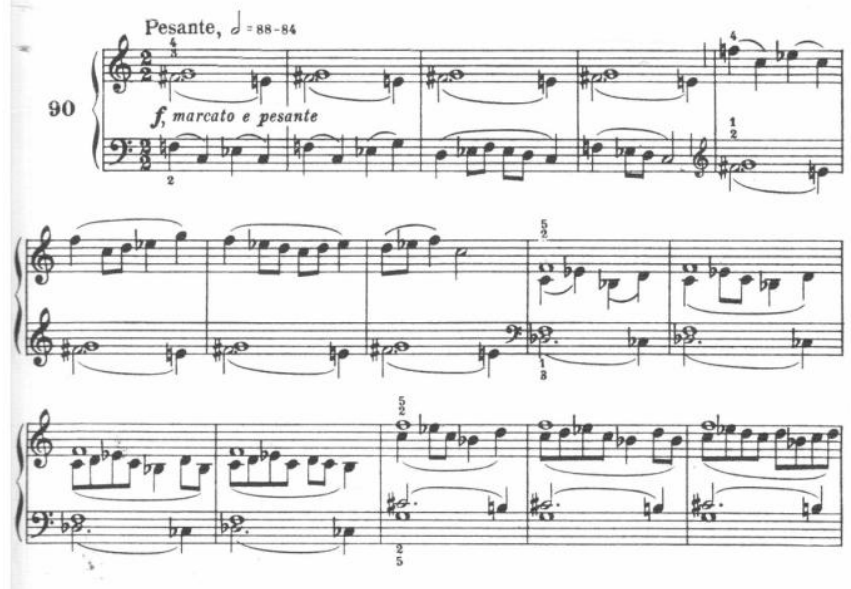

Fig. 2. Bela Bartók. "Microcosmos" for piano. No 90 "In the Russian style". 
Analysis of borrowings shows that among some of them there are very favorite ones by very different musicians. This hymns by Alexei Lvov, "God, Save the Tsar", romances "The Red Sarafan" by Alexander Varlamov and "Nightingale" by Alexander Alyabiev, lixes "Kamarinskaya", the Ukrainian song "The Cossack went for the Danube". Some of them were so popular that were considered as nearly national. Just so "The Red Sarafan" by Alexander Varlamov was interpreted in the names of their opuses by many Western authors. Virtually, for a long time the theme of romance played the role of "hallmark", "emblem" of Russian music. National-state status Varlamov's melody is confirmed by the experience of Austrian pianist Sigismond Thalberg, who connected in the "Variations on the two Russian Songs" Op. 17 (1836) for piano the theme "The Red Sarafan" and the national hymns "God, Save the Tsar".

On the other hand national hymns "God, Save the Tsar", from 1833 to 1917 symbolized Russia itself, freed from the verbal text of Vasily Zhukovsky, often loses its ritual pathos and sounds like a household song or placed into the context of modest household music. This happened in the "Russian mazurka" "Queen" by the French composer and conductor Louis-Gaston Ganne, in the beginning of which after fanfare the theme "God, Save the Tsar" is held twice, and then bright, playful salon music, not connected with it, appears (musical and a sound sample). It is clearly that front genre is relegated to the playful salon instrumental music and in "Fantasy on Russian national hymns" by Italian composer Pietro Pettoletti op. 15, supposed to guitar.

In comparison with the vocal or choral song and instrumental transcription, such a genre of Russian musical culture as a sacred chant appears in the works of Europeans much less. Here serious creative intentions of Giuseppe Sarti ("Now the powers of heaven", "Lord, have mercy") and Balthazar Galuppi (choral concerts) are particularly noteworthy. However, lesser interest of European to genres of Russian sacred music is quite natural and is caused by his distancing from the Orthodox Church as a religious belief.

It is interesting compositional methods and techniques of working with musical material. The simplest of them are widely used by Western masters method of variation. According to the vast number of foreign authors, the number of publications and concert programs, the greatest demand among the general public enjoyed the folk songs or ballads, designed for playing music on the piano, at least - violin, cello, guitar. They are attracted by the opportunity to demonstrate the mastery of the performing musician, who is often also found himself and the author of the play. A follower of Johann Sebastian Bach, which bears the title of "the famous virtuoso», Johann Gottfried Wilhelm Palschau (in 1741 - 1815) was one of the first European authors who applied to the end of the XVIII century to the Russian folk tunes with a view to its virtuoso concert develop and published three variation opuses.

Infrequent cases of the use of polyphony are significant. A follower of Johann Sebastian Bach, German composer, pianist, zimbalist, organist and teacher Johann Wilhelm Gessler, after the match in Dresden with Mozart was invited to Moscow. He caught the intonation similarities Russian songs and the Protestant chorale; it allowed him to combine the lyrical Russian melodiousness with Bach's counterpoint and continue the tradition of Bach's choral treatments. Giuseppe Sarti, while in general in the Western European musical tradition, long before Glinka realized the intention of the Russian classic "to connect fugue west to the features of our music with bonds of wedlock " [2. P. 180] (for example, in "fugue for eight real voices" "Lord have mercy"). Polyphonic - contrapuntal - technique was also in demand, while the combination of different borrowed themes.

\section{CONCLUSION}

Analysis of the musical works of European composers interaction of two called components of style shows that Russianness is quite attractive for a foreign musicians, as evidenced by numerous musical opuses are created in different genres until the present day. However, However, it has developed quite specific: the intention is not always received adequate creative solution. As, stated in the title of the program Russiannes can not extend to the actual music. Sometimes Russian conceals actually Ukrainian, Gypsy, Polish. Suffice selective contact European with folklore turns into a certain distancing from the Russian intonation roots. As a result, between the original intentions (even in the form of quoted Russian melodies) and cultivated traditions of the Western-European composer art, as a rule, a gap, a tear, a mismatch are formed. Thus, the real organics, the merger of West European and Russiannes is rarely achievable. (Examples thereof - "Fantasia on the Russian National Anthem" for organ and orchestra by Charles Gounod, "Russian funeral" for symphony orchestra by Benjamin Britten). This makes it possible to say that the European masters are rather motivated by a desire to show, to indicate, to declare the Russianness than to comprehend, to go deep and to get used to it.

Thus, a cursory review which we have undertaken shows that Russian culture is very attractive for Western composers. Their interest was based on both objective processes and events, as well as on the personal quest, experiments, and special creative assignments. They are seeking ways to "entry" in an alien for them musical environment and, on the contrary, the methods of initiation of the Russianness to the European traditions. Thanks to the efforts of many composers in the Western world, certain image of Russian music formed, heard by the European musical "ear" and the music of Russia enriches by the cultural conquests of Europe.

\section{REFERENCES}

[1] Yu.V. Vasilyev, "Rachmaninoff and jazz," S.V. Rachmaninoff, Dedicated to the 120th anniversary (1873 -1993), The Moscow State Tchaikovsky Conservatory, edit. A.I. Kandinsky, M.: 1995, pp. 172184.

[2] M.I. Glinka, Literature works and correspondence, M.I. Glinka, Complete edition, Vol. 2-B, M.: 1977.

[3] N.B. Dimitriadi, "Certain style properties of Russian music about the Orient," Journal of Music Theory, Issue 13, Edit. L.N. Raaben, L. Muzyka, 1974, pp. 106-125. 
[4] T.N. Livanova, "Sketches and materials about history of Russian musical culture," M.: Isskustvo, 1938.

[5] F. Liszt, Instrumental and vocal pieces of Russian composers in piano transcription, Edit. V.S. Belov, M.: Muzyka, 1952 (music text).

[6] D.A. Rakhimov, "Orientalism in music of S.V. Rachmaninoff," Thesis, Ph.D. in Art history, SPb. 2011.

[7] N.A. Ryzhkova, "Battle music in Russia," Early Music, No.2, M.:2002.

[8] N.A. Ryzhkova, "Music of patriotic war," Early Music, No.3, M.:2002.

[9] N.A. Ryzhkova, "Musical battles in Russia," Art Studies Magazine, No. 1-2, M., 2012.

[10] N.N. Sokolov, "The Orient theme in symphonic works by M.M. Ippolitov-Ivanov and the traditions of Russian oriental symphonic style," Thesis, Ph.D. in Art history, 1997.

[11] N.E. Tropina, "The Patriotic War of 1812 in Russian music (search for authentic sources)," Source Studies at School magazine, No. 1(10), M., 2011.

[12] N.F. Findeizen, "Sketches on music history in Russia from the earliest times until the end of the XVIII century," M.-L., Muzsektor Publishers, Vol. 2, Edition 5, 1928.

[13] Y.Y. Shtelin, "Music and ballet in Russia of the XVIII century," L.: Muzgiz, 1935. 